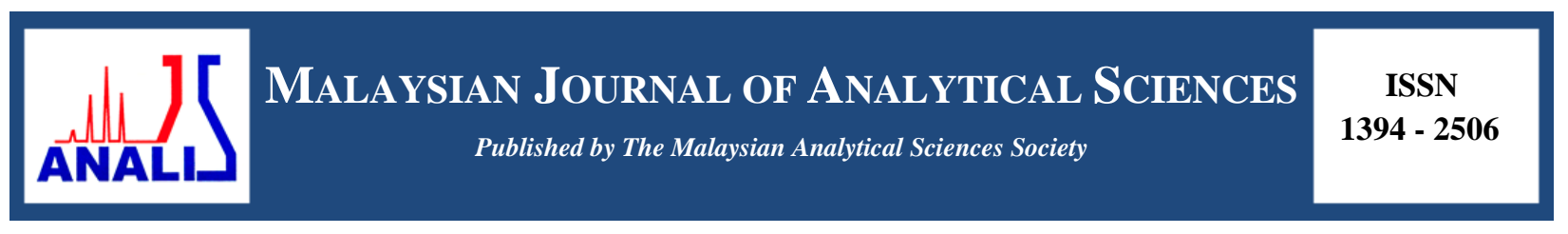

\title{
Moringa oleifera SEED DERIVATIVES AS POTENTIAL BIO-COAGULANT FOR MICROALGAE Chlorella Sp. HARVESTING
}

\author{
(Potensi Derivatif Biji Moringa oleifera sebagai Bio-Pengental untuk Penuaian Mikroalga \\ Chlorella sp.)
}

\author{
Azizah Endut ${ }^{1,2 *}$, Siti Hajar Abdul Hamid ${ }^{1}$, Fathurrahman Lananan $^{1}$, Helena Khatoon ${ }^{3}$ \\ ${ }^{1}$ East Coast Environmental Research Institute \\ ${ }^{2}$ Faculty of Innovative Design and Technology \\ Universiti Sultan Zainal Abidin, Gong Badak Campus, 21300 Kuala Terengganu, Terengganu, Malaysia \\ ${ }^{3}$ School of Fishery Science and Aquaculture, \\ Unversiti Malaysia Terengganu, 21030 Kuala Terengganu, Terengganu, Malaysia
}

*Corresponding author: enazizah@unisza.edu.my

Received: 14 April 2015; Accepted: 30 November 2015

\begin{abstract}
Microalgae is an economical and potential raw material of biomass energy, which offer a wide range of commercial potential to produce valuable substances for applications in aquaculture feed, pharmaceutical purposes and biofuels production. However, lack of an economical, efficient and convenient method to harvest microalgae is a bottleneck to boost their full-scale application. Hence, this study was performed to investigate the potentialities of Moringa oleifera seed derivatives as an environmentally biocoagulant to harvest microalgae Chlorella sp. biomass from the water column, which acts as a binder to coagulate particulate impurities to form larger aggregates. Results shown M. oleifera to have better biomass recovery of $122.51 \%$ as compared to $37.08 \%$ of alum at similar dosages of $10 \mathrm{mg} \cdot \mathrm{L}^{-1}$. In addition, it was found that the zeta potential values of mixed microalgaecoagulant suspension shows positive correlation on the flocculation parameters. For biomass recovery, the correlation for $M$. oleifera protein powder showed the $\mathrm{R}^{2}$-value of 0.9565 whereas the control chemical flocculant, alum with the $\mathrm{R}^{2}$-value of 0.7920. It was evidence that $M$. oleifera has a great potential in efficient and economical for environmentally microalgae harvesting and the adaptation of biological harvesting technology especially for the purpose of aquaculture feed in Malaysia.
\end{abstract}

Keywords: Chlorella sp., coagulation-flocculation, isoelectric point, Moringa oleifera, zeta potential

\begin{abstract}
Abstrak
Mikroalga merupakan bahan mentah yang murah dan berpotensi untuk tenaga biojisim, yang menawarkan pelbagai peluang pengkomersialan untuk menghasilkan bahan bernilai untuk aplikasi dalam makanan akuakultur, farmaseutikal dan penghasilan bahan bakar bio. Walaubagaimanapun, kekurangan kaedah yang murah, cekap dan mudah untuk penuaian mikroalga merupakan halangan untuk meningkatkan aplikasi teknologi ini dalam skala yang lebih besar. Oleh itu, kajian ini telah dijalankan untuk menyiasat potensi derivatif biji Moringa oleifera sebagai bio-penggumpal biojisim mikroalga Chlorella sp., yang bertindak sebagai pengikat untuk menggumpalkan zarah enapcemar membentuk agregat yang lebih besar dari kolum air. Keputusan menunjukkan $M$. oleifera mempunyai pemulihan biojisim yang lebih baik iaitu $122.51 \%$ berbanding alum iaitu $37.08 \%$ pada dos yang sama sebanyak $10 \mathrm{mg} \cdot \mathrm{L}^{-1}$. Di samping itu, nilai keupayaan zeta campuran mikroalga dan penggumpal menunjukkan kolerasi positif terhadap parameter penggumpalan. Dalam pemulihan biojisim, kolerasi bagi serbuk protein $M$. oleifera menunjukkan nilai $\mathrm{R}^{2}$ iaitu 0.9565 manakala penggumpal kimia kawalan, alum mempunyai nilai $\mathrm{R}^{2}$ iaitu 0.7920 . Ini membuktikan bahawa $M$. oleifera mempunyai potensi tinggi untuk penuaian mikroalga yang berkecekapan tinggi dan murah serta penyesuaian teknologi penuaian biologi terutamanya untuk tujuan makanan akuakultur di Malaysia.
\end{abstract}

Kata kunci: Chlorella sp., koagulasi-flokulasi, titik isoelektrik, Moringa oleifera, keupayaan zeta 


\section{Introduction}

The exploration of potential natural coagulant is crucial for sustainability in mass microalgae harvesting. Microalgae harvesting in mass cultivation industry consisting of two stage process involving bulk harvesting and thickening. Bulk harvesting was aimed at the separation of biomass from the bulk suspension using flocculation techniques whereas thickening concentrated the slurry through energy intensive techniques such as centrifugation and filtration [1]. Chemical coagulants normally applied in the bulk harvesting stage. Thus, microalgae harvesting in massive scale would require high amount of chemical flocculants, which is not sustainable for long-term green technology application. Natural coagulant could be investigated for the desired flocculation characteristics similar to chemical flocculants. Plant-based natural coagulant is more environmental friendly and not pose health risks as chemical flocculants such as aluminum and ferric salts. The use of inorganic coagulants such as ferric chloride, $\mathrm{FeCl}_{3}$ and aluminum sulfate, $\mathrm{Al}_{2}\left(\mathrm{SO}_{4}\right)_{3}$ shortly known as alum is proven to be effective for some microalgae flocculation, however it is certainly unacceptable if the harvested biomass is to be used for aquaculture purposes, animal feed or organic fertilizer. It was reported that the major component of alum and acrylamide could lead to human health implications, such as involvement in Alzheimer's disease and the cause of cancers [2]. According to Zheng et al. [3], these flocculants are required in high doses, both are more than $0.75 \mathrm{~g} \cdot \mathrm{L}^{-1}$ for microalgae harvesting.

In Malaysia, $M$. oleifera, commonly known as kacang merunggai is available locally and inexpensive hence making them a viable alternative to chemical coagulant in water and wastewater treatment, which is also possible as bioflocculants in the microalgae biomass separation process and harvesting [4]. Bio-coagulant from $M$. oleifera was reported to have a high flocculation potential in water treatment, attaining $92-97 \%$ flocculation efficiency [5, 6]. Previous study also concluded that $M$. oleifera seeds as a strong candidate as a bio-flocculant for microalgae harvesting at optimal $\mathrm{pH}$ range [7]. M. oleifera seed active compounds are known as the peptides of molecular weight ranging from 6 to $20 \mathrm{kDa}$, with an isoelectric $\mathrm{pH}$ value between 9 to $10[6,8]$.

Dispersion of microalgae cells in the water column leads to the difference of surface charges between microalgae biomass suspension and chemical ions of the cultivation media. According to Chen et al. [9], the proper reaction mechanisms existing at the colloid surfaces are differential loss ions from the crystal lattice because of the rupture of ionic or covalent bond, adsorption of charged species from the surrounding solution and ionization of chemical groups on the surface. The suspending microalgae cells in the water carried charge, which result in the generation of the electrical-double-layer. In solution, the presence of a net charge on a particle affects the distribution of ions surrounding it, resulting in an increase in the concentration of counter-ions. This region over which this influence extends was referred as electrical-double-layer. Conventionally, this layer is thought of as existing as two separate regions, which are inner region and outer layer. An inner region consists of strongly bound ions to the particle known as stern layer while the outer layer called diffuse layer associated with counter-ions. In the electrophoresis, an electric field is applied to a dispersion of particle, sometimes liquid droplets or even gas bubbles which gives rise to a motion of the charged particles with respect to the bulk liquid [10]. As the particle moves through solution, due to gravity or an applied voltage, the ions move with it. At some distance from the particle there exists a boundary, beyond which ions do not move with the particle. This is known as the surface of hydrodynamic shear, or the slipping plane which exists somewhere within the diffuse layer. During this phenomenon, the potential which is zeta potential do exists at the slipping plane.

The measurements of zeta potential is crucial in determining the stability of a colloidal suspension. Normally in a colloidal system, the dispersion are stable in which particles do not aggregate. The aggregation of particles in suspension depends on the magnitude of the zeta potential. In many instances stable dispersion are required. In other cases, such as water and wastewater treatment, paper manufacturing and oil recovery, unstable dispersion are desired. Stable or unstable dispersion could be produced in a variety of ways, which are by changing the $\mathrm{pH}$ of dispersion, addition of electrolyte and addition of coagulant. Generally, zeta potential study was correlated with coagulation-flocculation process. By measuring zeta potential, the isoelectric point (i.e.p.) in a colloidal system could be determined. Isoelectric point is very important from a practical consideration which normally indicated the least stable point in a colloidal system. At this point, the potential energy barrier opposing coagulation disappears, 
and it is called the critical coagulation concentration [11]. Effective coagulation process could be performed in order to remove or recover the colloids from its suspended system.

The nature of suspended microalgae and surface charge could make the solid-liquid separation more difficult. However, the determination of zeta potential could lead to the understanding of isoelectric point of a colloidal system and eased explanation of the mechanism and interfacial phenomena occurring during coagulationflocculation process of microalgae under various coagulants. The aim of this study was to explore the potential use of $M$. oleifera as a novel low cost bio-coagulant for microalgae Chlorella sp. harvesting. The interaction of the zeta potential of commercial coagulant which are alum, natural M. oleifera seed powder and M. oleifera protein powder in harvesting locally isolated freshwater microalgae, Chlorella sp. were investigated. The correlation of zeta potential and flocculation ability was explored to explain the interaction between coagulants and microalgae cells in suspended. Selected conditions for coagulation-flocculation were presented, as well as removal and microalgae biomass recovery percentage for different dosage at optimum $\mathrm{pH}$. In this study, the experimental strategy was focused on coagulation-flocculation process corresponding to the profiles of zeta potential with respect to $\mathrm{pH}$ for different coagulants used such as alum, M. oleifera seed powder and M. oleifera protein powder.

\section{Study area}

\section{Materials and Methods}

Microalgae maintenance and flocculation assays were carried out at the Institute of Tropical Aquaculture, Universiti Malaysia Terengganu, Terengganu. The determination of zeta potential of microalgae suspension and M. oleifera seed derivatives were performed at the Civil Engineering Lab, Department of Civil Engineering, Universiti Putra Malaysia, Selangor.

\section{Preparation of alum stock solution}

Stock solution of aluminum sulfate $\left(10 \mathrm{mg} \cdot \mathrm{L}^{-1} \mathrm{Al}^{3+}\right)$ supplied by Sigma Aldrich was prepared by dissolving $1 \mathrm{~g}$ of dry solid in $99 \mathrm{~mL}$ of deionized water. The alum powder was totally soluble in the water. A fresh solution was prepared every day for reliable results. In this study, the zeta potential of alum was compared with natural coagulants of $M$. oleifera seed powder and protein powder in harvesting freshwater microalgae, Chlorella sp..

\section{Cultivation of freshwater microalgae, Chlorella sp.}

The inoculum of pure culture of freshwater microalgae, Chlorella sp. was obtained from the microalgae culture collections of the Live Feed Culture Lab, Institute of Tropical Aquaculture, Universiti Malaysia Terengganu, Malaysia. Chlorella sp. was cultivated in Bold's Basal Medium (BBM) with controlled temperature of $25 \pm 2{ }^{\circ} \mathrm{C}$ and $24 \mathrm{~h}$ illumination at 3350 lumen until late exponential phase in which cell density reached averagely $2.0 \times 10^{7}$ cells $\cdot \mathrm{mL}^{-1}$.

\section{Spectrophotometric analysis of Chlorella sp. biomass}

The Chlorella sp. biomass were measured using spectrophotometric colorimetric method to facilitate rapid measurement. Spectrum analysis was performed to determine the peak absorption wavelength for the spectrophotometric colorimetric technique which was at $686 \mathrm{~nm}$. For the establishment of standard calibration curve, Chlorella sp. biomass was measured using haemocytometer (Marienfield Neubauer-improved $0.1 \mathrm{~mm}$ depth, Germany) and syringe liquid sampler particle system (PMS SLS-2000, USA).

\section{Preparation of M. oleifera seed powder}

M. oleifera seeds were obtained within the region of Kuala Terengganu, Malaysia. The plant were authenticated by the Faculty of Bioresources and Food Industry, Universiti Sultan Zainal Abidin (UniSZA) Tembila, Terengganu, Malaysia. The plant was deposited at the university herbarium. The collected dry pods were unshelled to obtain the seeds. Pods shells were removed manually and only qualified contaminant-free seeds were selected to be used as coagulant. Then, the seeds consisted of cupule, seed coat and seed kernel were grounded using laboratory mill and sieved through $600 \mu \mathrm{m}$ stainless steel sieve to obtain homogenous fine powders from each seed structure. 


\section{Azizah et al: Moringa Oleifera SEED DERIVATIVES AS POTENTIAL BIO-COAGULANT FOR MICROALGAE Chlorella Sp. HARVESTING}

\section{Purification of M. oleifera seed protein}

The procedures for the purification of $M$. oleifera coagulation polymer were carried out based on Kwaambwa, and Maikokera method [12]. Dried de-oiled M. oleifera powder was used for the extraction of coagulant protein polymer. The extraction was performed by adding 3\% (w/v) $\mathrm{NaCl}$ solution and this suspension was continuously agitated for $12 \mathrm{~h}$ in orbital shaker at controlled temperature of $25 \pm 2{ }^{\circ} \mathrm{C}$. The extract was filtered with Whatman filter No.44 and further heated in such a way that no white precipitation is formed at the bottom of solution. The heated crude protein extract solution was then poured into the dialysis tube and submerged completely for $12 \mathrm{~h}$ with constant temperature of $2 \pm 2{ }^{\circ} \mathrm{C}$. After completion of the dialysis procedure, the salt present in the crude brown protein was osmotically extracted into the surrounding water solution leaving white protein extract inside the dialysis tube. Then, the protein was dried at room temperature to form fine protein powder.

\section{Coagulation-flocculation and sedimentation experiments}

Coagulants tested in this study included alum, M. oleifera seed powder and M. oleifera protein powder. Coagulation-flocculation and sedimentation experiments were performed in glass beakers $0.12 \mathrm{~m}$ height by $0.09 \mathrm{~m}$ diameter $(\mathrm{h} / \mathrm{D}=1.33)$ using a $250 \mathrm{~mL}$ microalgae volume. Flocculants, previously dissolved in water at concentration $10 \mathrm{mg} \cdot \mathrm{L}^{-1}$ were added to the microalgae sample under intense stirring at $150 \mathrm{rpm}$ for 3 minutes to ensure complete solubility of the flocculants. Following that, the stirring was reduced to gentle agitation at $20 \mathrm{rpm}$ for 20 minutes, so as to initiate flocs formation. After that, the suspension was leaved for sedimentation in 20 minutes. When interphases appear, it was clear and $3 \mathrm{~mL}$ sample was taken at the top (clear supernatant) for removal efficiency and $3 \mathrm{~mL}$ from bottom (saturated Chlorella sp. biomass) for biomass recovery. The absorbance of the sample were measured using UV-vis spectrophotometer (Shimadzu UV-1800, Japan). All experiments were carried out in triplicates. Percentage of biomass removal was calculated from the absorbance ratio at clarified zone against the culture absorbance at the beginning of the experiment according to Equation 1:

$$
\text { Biomass removal }(\%)=\frac{A b s_{668} \text { initial culture }- \text { Abs } 668 \text { clarified zone }}{A b s_{668} \text { initial culture }} \times 100
$$

\section{Measurements of zeta potential}

Methods of measuring zeta potential on a particles dependent both which are the particle and the suspension formulation. In general, the size and concentration of particles are the key parameters that determine which technique is applicable. In this study, zeta potential was measured based on the dispersion concentration of each coagulants which are alum, $M$. oleifera seed powder and $M$. oleifera protein powder in water at room temperature. Zeta potential was not measured directly. Perhaps the most widely used technique for measuring zeta potentials in electrophoresis. By applying an electric field across the sample, charged particles were induced to move. The velocity of particles known as electrophoretic mobility (EM). The electrophoresis measurements were carried out by injecting $25 \mathrm{~mL}$ of the aqueous dispersions of each coagulants into the cell of zeta potential instrument (Zeta-Meter System 3.0+, USA) at room temperature. The electrophoresis cell holds the sample for viewing under the microscope. It consists of two electrode chambers connected by an optically polished electrophoresis tube which is $10 \mathrm{~cm}$ long and $4 \mathrm{~mm}$ in diameter. Zeta potential measurements also was performed on suspending freshwater microalgae, Chlorella sp. culture before and after the addition of coagulants in order to investigate the effects of coagulants on its isoelectric point. By directly measuring the electrophoretic mobility of particle in dispersion, the zeta potential was determined using Henry's Equation 2 [13]:

$$
\mu=\frac{2 \varepsilon_{0} \varepsilon_{r} \zeta f(\kappa r)}{3 \eta}
$$

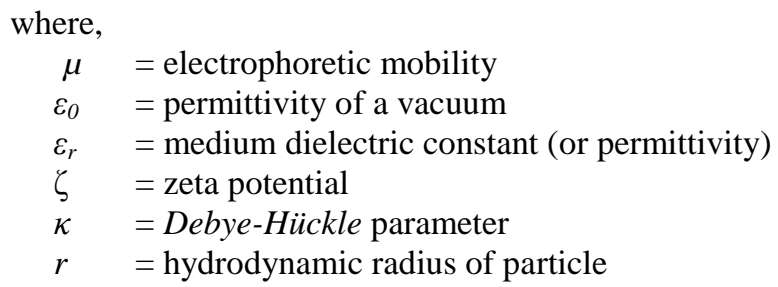

$$
\begin{array}{cl}
\eta & =\text { viscosity of medium } \\
f(\kappa r) & =\text { Henry's function }
\end{array}
$$


The Henry's function generally has value either 1.5 or 1.0. For the measurements of zeta potential in aqueous solutions of moderate electrolyte concentration, a value of 1.5 is used. In this study, zeta potential was calculated according to the Henry's equation, applying Smoluchowski approximation [14].

\section{Statistical analysis}

Zeta potential of Chlorella sp., alum, M. oleifera seed powder and M. oleifera protein powder with respect to $\mathrm{pH}$ were recorded in Microsoft Office Excel ${ }^{\mathrm{TM}}$ throughout the experimental period. Graphical analyses were performed using Originlab OriginPro $8.6^{\mathrm{TM}}$ whereas the statistical determination involving One-Way ANOVA and post-hoc analysis utilizing Tukey's HSD Test were implemented via Minitab $16^{\mathrm{TM}}$. A confidence level of $95 \%(\alpha=0.05)$ was selected in order to strictly determine the significance of between the dosages and types of coagulant used with the dependent parameters on microalgae biomass recovery.

\section{Zeta potential analysis}

\section{Results and Discussion}

Figure 1 shows the zeta potential values of freshwater microalgae, Chlorella sp. biomass and M. oleifera seed derivatives suspension in the range of $\mathrm{pH} 2$ to $\mathrm{pH} 12$. Both M. oleifera seed powder and M. oleifera protein powder zeta potential values decreases from 45.68 and $28.51 \mathrm{mV}$ at $\mathrm{pH} 2$ to the zeta potential values of -38.59 and -15.93 $\mathrm{mV}$ at $\mathrm{pH} 11$, respectively. Control coagulant, alum also had decreased zeta potential value as $\mathrm{pH}$ increased from $\mathrm{pH} 2$ to $\mathrm{pH} 12$ with the value of 59.64 to $-38.40 \mathrm{mV}$. In addition, Chlorella sp. biomass exhibited moderate decrease of the zeta potential value from -24.15 to $-49.99 \mathrm{mV}$ at $\mathrm{pH} 2$ to $\mathrm{pH} 11$. As shown in Table 1, Chlorella sp., alum and M. oleifera protein powder had significant regression with the Boltzmann Sigmoidal Model with the $\mathrm{R}^{2}$-values of $0.9512,0.9965$ and 0.9549 , respectively. Zeta potential values of Chlorella sp. and coagulants at various $\mathrm{pH}$ fitted with the model were shown in Figure 2.

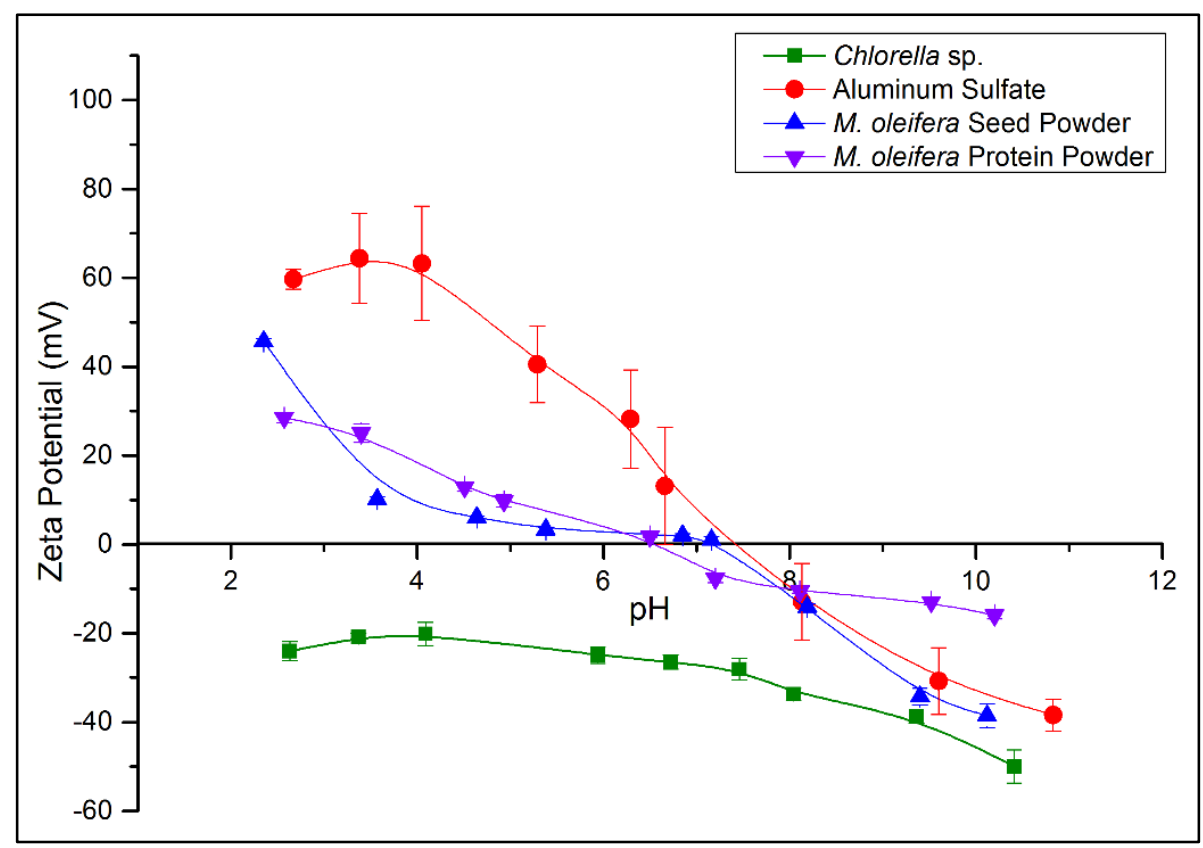

Figure 1. Spline curves of zeta potential values of Chlorella sp., aluminum sulfate, M. oleifera seed powder and $M$. oleifera protein powder at various $\mathrm{pH}$. 
Azizah et al: Moringa Oleifera SEED DERIVATIVES AS POTENTIAL BIO-COAGULANT FOR

MICROALGAE Chlorella Sp. HARVESTING

Table 1. Boltzmann sigmoidal parameters of zeta potential at various $\mathrm{pH}$ for microalgae, Chlorella sp. and several coagulant suspensions

\begin{tabular}{|c|c|c|c|c|c|c|}
\hline \multirow{2}{*}{ Suspension } & \multirow{2}{*}{$\begin{array}{c}\text { Reduced } \\
\text { Chi-Square }\end{array}$} & \multirow{2}{*}{$\begin{array}{l}\text { Adjusted R- } \\
\text { Square }\end{array}$} & \multicolumn{4}{|c|}{ Boltzmann Sigmoidal Fit } \\
\hline & & & $\begin{array}{c}\text { Initial Value, } \\
\mathbf{A}_{1}\end{array}$ & $\begin{array}{c}\text { Final Value, } \\
\mathbf{A}_{2}\end{array}$ & $\begin{array}{c}\text { Centre, } \\
\mathrm{X}_{0}\end{array}$ & $\begin{array}{c}\text { pH Constant, } \\
\text { dx }\end{array}$ \\
\hline Chlorella sp. & 1.1477 & 0.9512 & $\begin{array}{l}-19.7754 \\
\pm 2.6250\end{array}$ & $\begin{array}{l}-83.0073 \\
\pm 110.0826\end{array}$ & $\begin{array}{l}10.8864 \\
\pm 6.1201\end{array}$ & $\begin{array}{c}2.0215 \\
\pm 1.4815\end{array}$ \\
\hline $\begin{array}{l}\text { Aluminum } \\
\text { Sulfate }\end{array}$ & 0.1779 & 0.9965 & $\begin{array}{l}62.6897 \\
\pm 2.2368\end{array}$ & $\begin{array}{l}-41.5764 \\
\pm 3.4869\end{array}$ & $\begin{array}{c}6.9651 \\
\pm 0.1999\end{array}$ & $\begin{array}{c}1.1466 \\
\pm 0.2026\end{array}$ \\
\hline $\begin{array}{l}\text { M. oleifera } \\
\text { Seed Powder }\end{array}$ & 112.9585 & 0.6962 & $\begin{array}{c}411055.3 \pm \\
1.2849 \times 10^{10}\end{array}$ & $\begin{array}{c}-1.7475 \pm \\
7.0051\end{array}$ & $\begin{array}{c}-8.5312 \pm \\
37406.3888\end{array}$ & $\begin{array}{c}1.1958 \pm \\
2.5013\end{array}$ \\
\hline $\begin{array}{l}\text { M. oleifera } \\
\text { Protein } \\
\text { Powder }\end{array}$ & 8.8414 & 0.9549 & $\begin{array}{c}32.8811 \pm \\
11.2681\end{array}$ & $\begin{array}{c}-18.9550 \pm \\
5.3989\end{array}$ & $\begin{array}{c}5.7435 \pm \\
0.6186\end{array}$ & $\begin{array}{c}1.6050 \pm \\
0.6980\end{array}$ \\
\hline
\end{tabular}

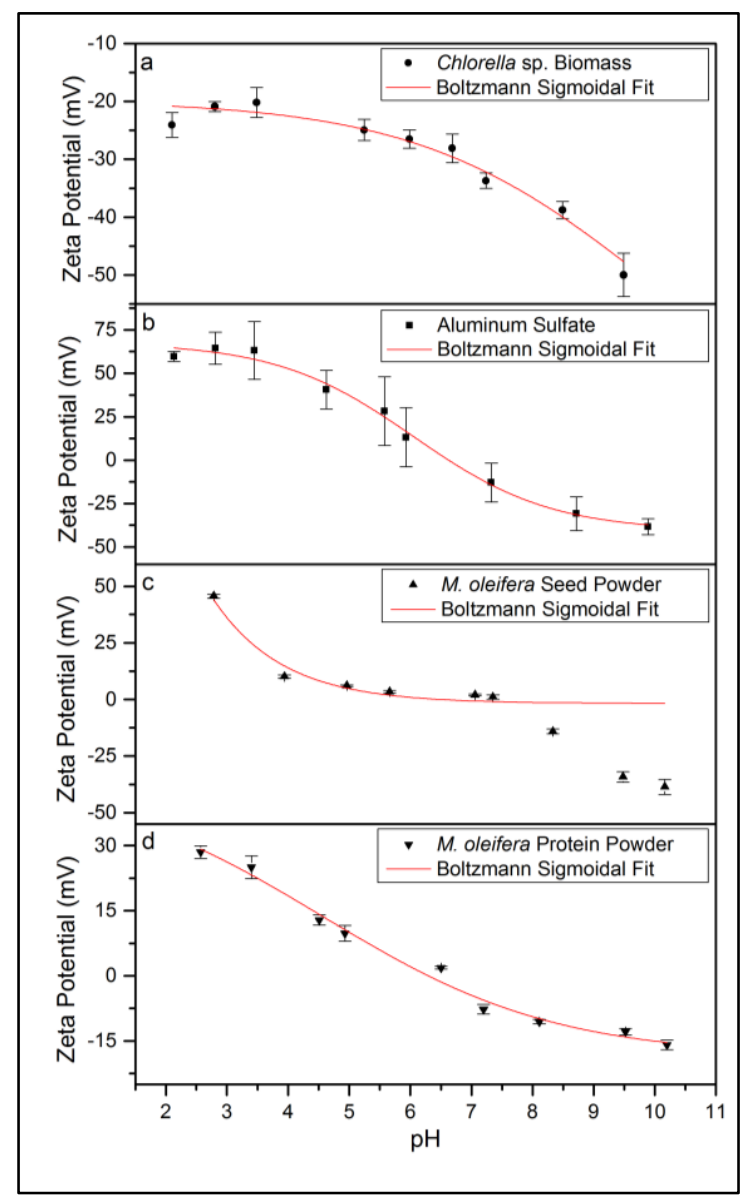

Figure 2. Zeta potential values of Chlorella sp. (a), aluminum sulfate (b), M. oleifera seed powder (c) and $M$. oleifera protein powder (d) at various $\mathrm{pH}$ fitted with Boltzmann Sigmoidal Model. 
Through the model fittings, it was found that the initial zeta potential values were respectively $-19.78,62.69$ and $32.88 \mathrm{mV}$ for Chlorella sp., alum and M. oleifera protein powder. Whereas, the predicted final zeta potential values were respectively $-83.01,-41.58$ and $-18.96 \mathrm{mV}$. The zeta potential of $M$. oleifera seed powder however could not be fitted with the sigmoidal model which yield $\mathrm{R}^{2}$-value of 0.6962 . In order to harvest the Chlorella sp. biomass, the coagulants were mixed at various coagulant dosages with the microalgae biomass undergoing flocculation assay and also yielded the mixed suspension zeta potential values and flocculation performance which were removal efficiency and biomass recovery, which were shown in Figure 3 and Figure 4, respectively.

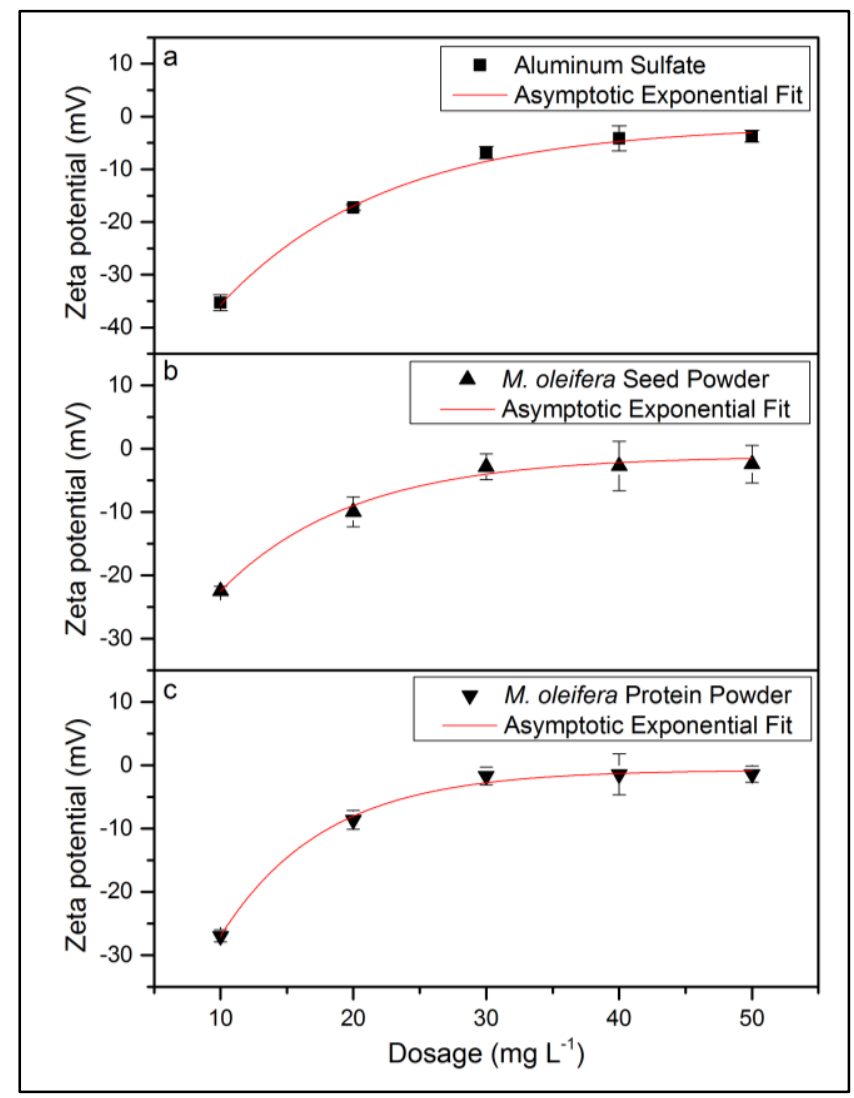

Figure 3. Zeta potential values of Chlorella sp. suspension mixed with aluminum sulfate (a), M. oleifera seed powder (b), M. oleifera protein powder (c) at various coagulant dosages fitted with Asymptotic Exponential Model.

The observed zeta potential values were further analyzed through fitting with the Asymptotic Exponential Model to optimize the coagulant dosage. It was found that the mixed suspension of Chlorella sp. with M. oleifera protein powder yield the highest i.e.p. of $-0.74 \mathrm{mV}$ as compared to -1.13 and $-1.62 \mathrm{mV}$ respectively for $M$. oleifera seed powder and alum at the dosage of $50 \mathrm{mg} \cdot \mathrm{L}^{-1}$. Higher i.e.p. values of $M$. oleifera seed protein suggested that it would have better flocculation rate as compared to M. oleifera seed powder and alum. In addition, M. oleifera protein powder also had the highest response range of $94.50 \mathrm{mV}$ whereas $M$. oleifera seed powder had the lowest zeta potential response range of $58.23 \mathrm{mV}$ as dosage increased from $0 \mathrm{mg} \cdot \mathrm{L}^{-1}$ to $50 \mathrm{mg} \cdot \mathrm{L}^{-1}$. Aluminum sulfate showed the highest rate of $0.92 \mathrm{mV}$ per $\mathrm{mg} \cdot \mathrm{L}^{-1}$ increase of coagulant followed by $M$. oleifera seed powder and seed protein, respectively 0.90 and $0.88 \mathrm{mV}$ per $\mathrm{mg} \cdot \mathrm{L}^{-1}$. This value shows that the $\zeta$-potential value of Chlorella sp. was highly correlated to the dosage of coagulant used. The addition of dosage cause the value of $\zeta$-potential increase. The 
increasing of $\zeta$-potential value indicate the disturbance on the stability of microalgal cells suspension. This is due to the charge neutralization of negatively charged cells with the addition of positively charged coagulants. Same trend was also observed by Muyibi et al. [15] which stated that the gradual decreased in biomass recovery was due to over dosage that led to restabilization of the destabilized suspended solids which previously had agglomerated into flocs.

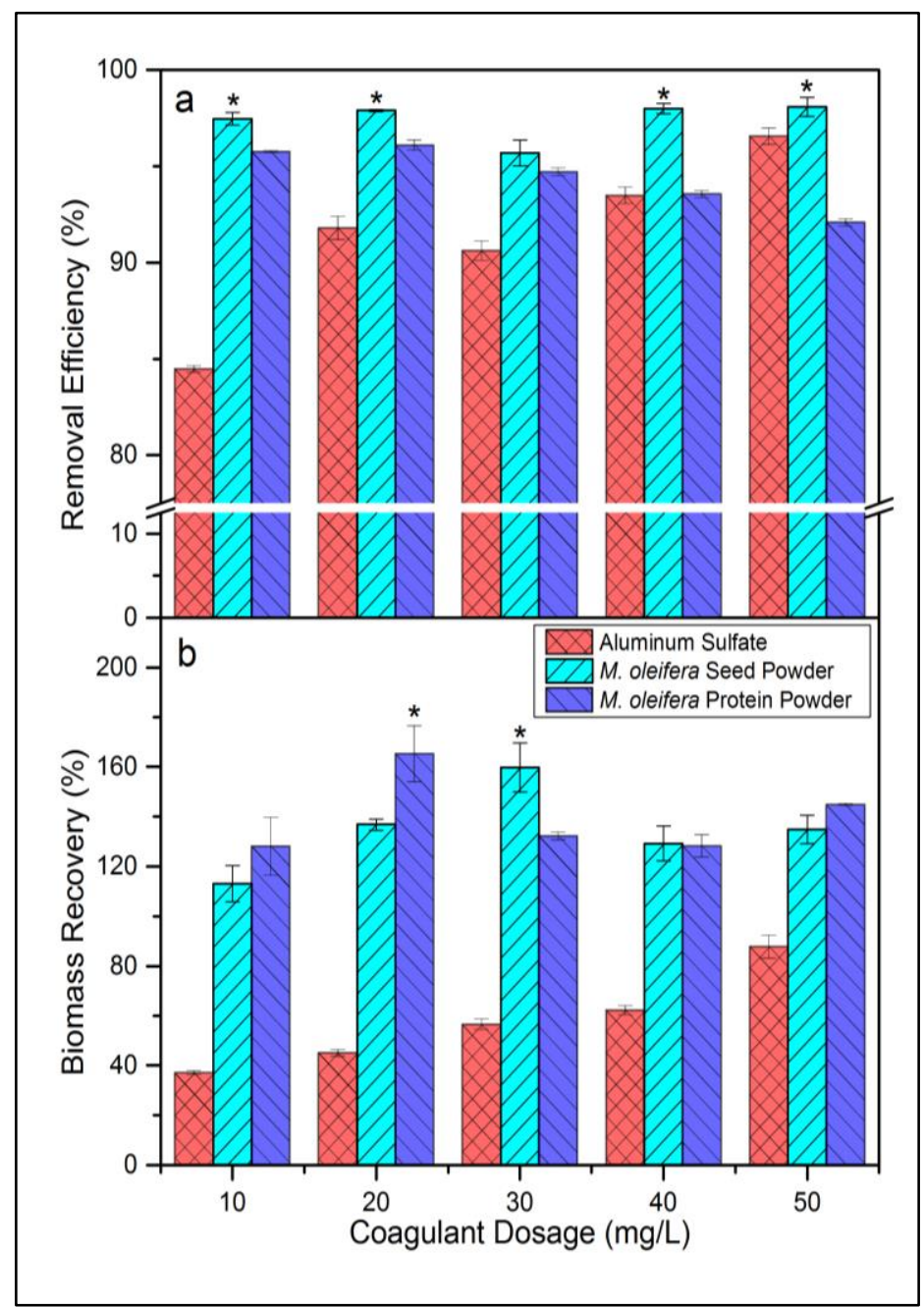

Figure 4. Removal efficiency (a) and biomass recovery (b) of aluminum sulfate, M. oleifera seed powder and $M$. oleifera protein powder at various coagulant dosages. Treatment with the significantly highest values was marked with asterisk $(*)$.

\section{Flocculation assays}

Flocculation performance of coagulant consisted of removal efficiency and biomass recovery. Removal efficiency is the effectiveness of coagulant in removing the suspended particles from the water column producing a clear supernatant. Meanwhile, biomass recovery is its proficiency in aggregating, settling and compacting the suspended particles at the bottom of the jar test vessel. Figure 4 showed the removal efficiency and biomass recovery of alum, M. oleifera seed powder and M. oleifera seed derivatives with regards to various coagulant dosage of 10 to 50 $\mathrm{mg} \cdot \mathrm{L}^{-1}$. M. oleifera seed powder achieved significantly highest $(\mathrm{P}<0.05)$ removal efficiency of above $97 \%$ at coagulant dosage of $10,20,30,40$ and $50 \mathrm{mg} \cdot \mathrm{L}^{-1}$ as compared to other coagulants. The removal efficiency of alum 
increased as dosage were increased but $M$. oleifera protein powder showed opposite trend. It could be observed that the maximum removal efficiency for M. oleifera protein powder was $96.09 \%$ at dosage of $20 \mathrm{mg} \cdot \mathrm{L}^{-1}$ and decreased to $92.08 \%$ as the dosage increased to $50 \mathrm{mg} \cdot \mathrm{L}^{-1}$. M. oleifera seed powder however showed consistent removal efficiency among various dosages. All coagulants showed increased biomass recovery as the dosage was increased up to $50 \mathrm{mg} \cdot \mathrm{L}^{-1}$. M. oleifera protein powder had the significantly highest biomass recovery of $207.46 \%$ as compared to other coagulants. M. oleifera seed powder, however only showed increased biomass recovery at the dosage of 10 to $30 \mathrm{mg} \cdot \mathrm{L}^{-1}$ with the maximum percentage of $159.78 \%$. At the dosage of $40 \mathrm{mg} \cdot \mathrm{L}^{-1}$, the biomass recovery decreased at $30.48 \%$. This negative relationship could be explained by the continuous addition of coagulant exceeding the optimum dosage which leads to the formation of excess coagulant residue since all of the available suspended microalgae already formed larger colloids [6].

Table 2 shows the coefficients for Asymptotic Exponential Model with the $\mathrm{R}^{2}$-value of $1.4443,0.3026$ and 0.4537 for Chlorella sp. suspension with aluminum sulfate, M. oleifera seed powder and M. oleifera protein powder, respectively. In addition, the output of the flocculation assays showed the ability of $M$. oleifera seed extracts not only in harvesting but also concentrate the recovered Chlorella sp. biomass for up to $159.78 \%$ and $207.46 \%$, respectively for $M$. oleifera seed powder and M. oleifera protein powder. The performance of $M$. oleifera seed powder was confirmed by Teixeira et al. [4] which reported its performance in harvesting marine microalgae from cultivation medium with the removal efficiency of more than $90 \%$. Nevertheless, other research involving the investigation on M. oleifera protein powder was still lacking.

Table 2. Asymptotic exponential parameters of zeta potential at various $\mathrm{pH}$ for mixed suspension of microalgae, Chlorella sp. with coagulants.

\begin{tabular}{|c|c|c|c|c|c|}
\hline \multirow{2}{*}{$\begin{array}{l}\text { Microalgae + } \\
\text { Coagulants }\end{array}$} & \multirow{2}{*}{$\begin{array}{c}\text { Reduced } \\
\text { Chi-Square }\end{array}$} & \multirow{2}{*}{$\begin{array}{l}\text { Adjusted } \\
\text { R-Square }\end{array}$} & \multicolumn{3}{|c|}{ Asymptotic Exponential Fit } \\
\hline & & & Asymptote, a & Response Range, $b$ & Rate, c \\
\hline $\begin{array}{l}\text { Chlorella sp. }+ \\
\text { Aluminum Sulfate }\end{array}$ & 1.4443 & 0.9844 & $-1.6233 \pm 1.7103$ & $75.8976 \pm 8.6003$ & $0.9232 \pm 0.0096$ \\
\hline $\begin{array}{l}\text { Chlorella sp. + } \\
\text { M. oleifera Seed } \\
\text { Powder }\end{array}$ & 0.3026 & 0.9919 & $-1.1332 \pm 1.6076$ & $58.2269 \pm 10.3332$ & $0.9046 \pm 0.0212$ \\
\hline $\begin{array}{l}\text { Chlorella } \text { sp. }+ \\
\text { M. oleifera Protein } \\
\text { Powder }\end{array}$ & 0.4537 & 0.9952 & $-0.7401 \pm 0.8427$ & $94.5035 \pm 14.6837$ & $0.8799 \pm 0.0151$ \\
\hline
\end{tabular}

\section{Correlation of zeta potential values and flocculation performance}

Prior to the correlation analysis, the zeta potential values of mixed suspension of Chlorella sp. and coagulants were fitted with the Asymptotic Exponential Model yielding the i.e.p. value (asymptote), zeta potential response range and rate of zeta potential change regarding dosage. Figure 5 shown the correlation of zeta potential and biomass recovery. M. oleifera protein powder showed the highest correlation between the zeta potential values and mean biomass recovery with the $\mathrm{R}^{2}$ value of 0.9565 . This was followed by alum and M. oleifera seed powder with $\mathrm{R}^{2}-$ value of 0.7920 and 0.7059 , respectively. For alum, biomass recovery decreased beyond the dosage of $30 \mathrm{mg} \cdot \mathrm{L}^{-1}$ which was inconsistent with the measured zeta potential. Same trend was also observed by Muyibi et al. [5], which stated that the gradual decreased in biomass recovery was due to over dosage that led to restabilization of the destabilized suspended solids which previously had agglomerated into flocs.

Correlation of zeta potential values and flocculation performance involved the use of zeta meter and only jar tests in which only coagulation/flocculation and settling processes were employed. It is therefore recommended that investigations be carried out through pilot plant studies which involves continuous biomass harvesting and various unit operations and processes employed for mass microalgae cultivation. Some studies reported that flocculation of microalgae can occur spontaneously without the need for chemicals, referred to as autoflocculation which can be 


\section{Azizah et al: Moringa Oleifera SEED DERIVATIVES AS POTENTIAL BIO-COAGULANT FOR MICROALGAE Chlorella Sp. HARVESTING}

induced by increasing the medium pH [16]. According to Harith et al. [17], harvesting efficiency of Chaetoceros calcitrans of higher than $90 \%$ was achieved by adjusting the culture $\mathrm{pH}$ to 10.2 using either $\mathrm{NaOH}$ or $\mathrm{KOH}$. The alteration of $\mathrm{pH}$ of the culture medium lead to the changes in the zeta potential and hence reduce the colloidal stability. In this study, the addition of coagulant dosage reduce the zeta potential of the microalgae colloidal and increased the biomass recovery percentage. On the other hand, the usage of non-toxic organic polymer, such as polyacrylamide copolymers, chitosan, and cationic starch have been intensively investigated for large-scale applications $[18,19]$. Unfortunately, they are not economical for microalgae due to its higher price. The coagulant residuals in both algal biomass and harvested water are not only negative for downstream processing but also reduce the possibilities for culture medium recycling.

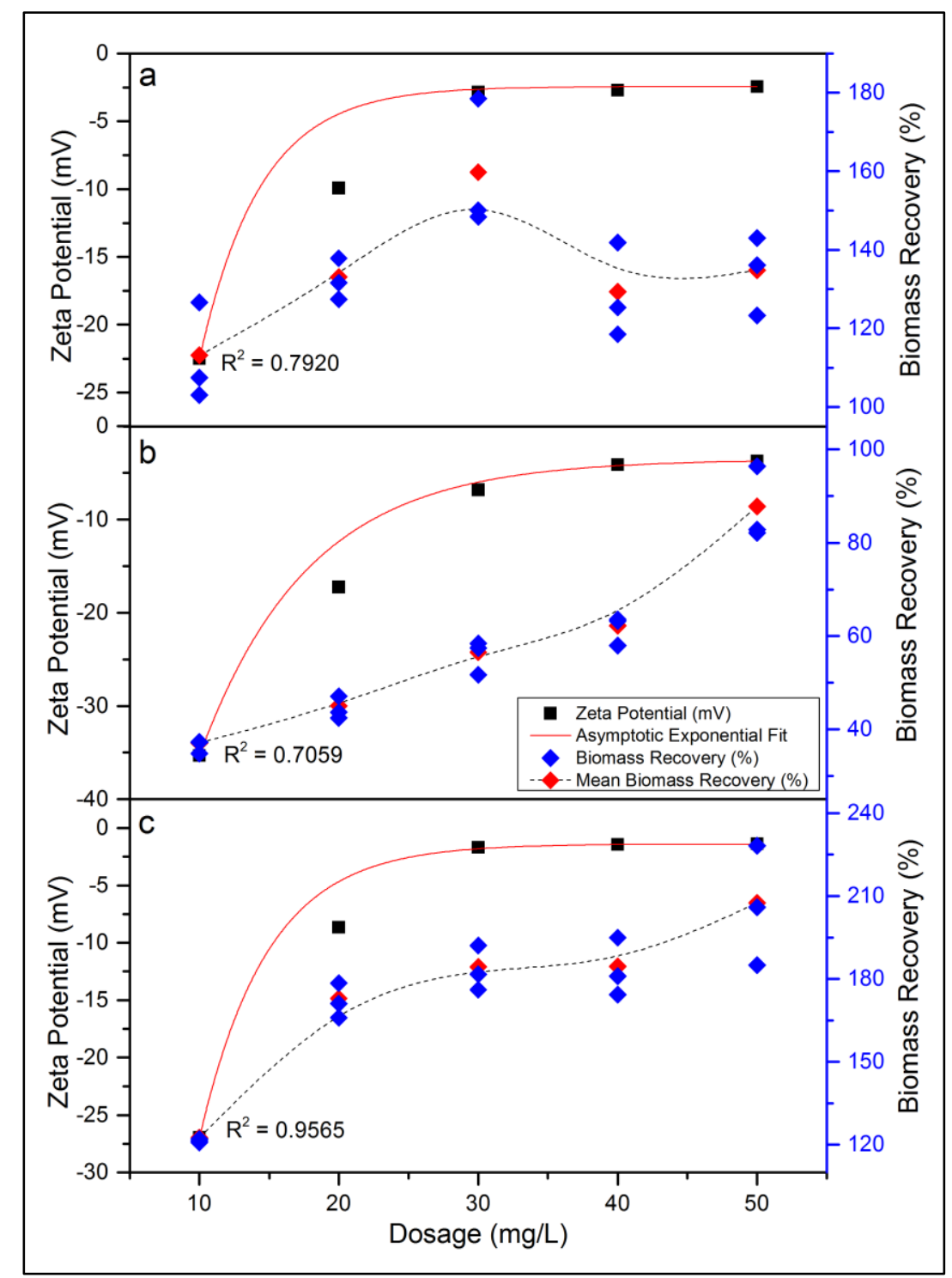

Figure 5. Correlation curves between zeta potential values and biomass recovery of aluminum sulfate (a), $M$. oleifera seed powder (b) and M. oleifera protein powder (c). 


\section{Conclusion}

In addition to the traditional practice of conventional water treatment, $M$. oleifera seed and protein powder as bioflocculant was proven to be a highly potential alternative to the chemical flocculant in harvesting microalgae Chlorella sp. biomass from the culture medium. Indeed, both $M$. oleifera seed derivatives had a higher removal efficiency and biomass recovery as compared to alum even at low dosage. M. oleifera seed derivatives were also found to concentrate the density of harvested microalgae to about twofold the initial density. It was also found that the application of the zeta potential determination to predict the flocculation performance of coagulant was probable since both value was highly correlated. Further investigation on the interaction of the zeta potential of $M$. oleifera seed derivatives on the flocculation of different microalgae species is highly recommended. The use of M. oleifera seed derivatives as bio-flocculant could assist in lowering the economic cost and providing environmentallyfriendly approach for mass microalgae cultivation and the sustainable development of bio-based renewable energy in the future.

\section{Acknowledgement}

The authors would like to thank the Ministry of Education of Malaysia for financially support this research under the Fundamental Research Grant Scheme (FRGS), project no. FRGS/1/2014/STWN01/UNISZA/02/2.

\section{References}

1. Brennan, L. and P. Owende. (2010). Biofuels from microalgae - A review of technologies for production, processing, and extractions of biofuels and co-products. Renewable and Sustainable Energy Reviews, 14(2). $557-577$.

2. Ahmad, A. L., Yasin, N. M., Derek, C. J. C. and Lim, J. K. (2011). Optimization of Microalgae Coagulation Process using Chitosan. Chemical Engineering Journal, 173(3): 879 - 882.

3. Zheng, H. Gao, Z. Yin, J. Tang, X. Ji, X. and Huang, H. (2012). Harvesting of Microalgae by Flocculation with Poly ( $\gamma$-glutamic acid). Bioresource Technology. 112. $212-220$.

4. Teixeira, C. M. L. L., Kirsten, F. V. and Teixeira, P. C. N. (2012). Evaluation of Moringa oleifera seed flour as a flocculating agent for potential biodiesel producer microalgae. Journal of Applied Phycology. 24(3). 557 - 563.

5. Muyibi, S. A. and Evison, L. M. (1995). Moringa Oleifera Seeds for Softening Hardwater. Water Research. 29(4): 1099 - 1104.

6. Ndabigengesere, A. and Narasiah, K. S. (1998). Quality of Water Treated by Coagulation using Moringa Oleifera Seeds. Water Research. 32(3). $781-791$.

7. Bilanovic, D., Andargatchew, A., Kroeger, T. and Shelef, G. (2009). Freshwater and Marine Microalgae Sequestering Of $\mathrm{CO}_{2}$ At Different C And N Concentrations - Response Surface Methodology Analysis. Energy Conversion and Management. 50(2). $262-267$.

8. De Godos, I., Mendoza, J. L., Acién, F. G., Molina, E., Banks, C. J., Heaven, S. and Rogalla, F. (2014). Evaluation of Carbon Dioxide Mass Transfer in Raceway Reactors for Microalgae Culture using Flue Gases. Bioresource Technology, 153: 307 - 314.

9. Chen, L., Zhang, G., Wang, L., Wu, W. and Ge, J. (2014). Zeta Potential of Limestone in A Large Range of Salinity. Colloids and Surfaces A: Physicochemical and Engineering Aspects, 450: $1-8$.

10. Moncho, A., F. Martínez-López and Hidalgo-Álvarez, R. (2001). Comparative Study of Theories of Conversion of Electrophoretic Mobility into $\zeta$-potential. Colloids and Surfaces A: Physicochemical and Engineering Aspects. 192(1-3). $215-226$.

11. Ofir, E., Oren, Y. and Adin, A. (2001). Electroflocculation: The Effect of Zeta-potential on Particle Size. Desalination, 204(1-3): $33-38$.

12. Kwaambwa, H. and Maikokera, R. (2007). A Fluorescence Spectroscopic Study of A Coagulating Protein Extracted from Moringa Oleifera Seeds. Colloids and surfaces B: Biointerfaces. 60(2): 213 - 220.

13. Hunter, R. J. (2001). Measuring Zeta Potential In Concentrated Industrial Slurries. Colloids and Surfaces A: Physicochemical and Engineering Aspects. 195(1-3): 205 - 214.

14. Smoluchowski, M. (1967). Investigation into A Mathematical Theory of the Kinetics of Coagulation of Colloidal Solutions. Physical Chemistry 92:129-168. 
15. Muyibi, S. A., Abas, S. A. A., Megat Johari, M. M., and Ahmadun, N. F. R. (2003). Enhanced Coagulation Efficiency of Moringa Oleifera Seeds through Selective Oil Extraction. IIUM Engineering Journal, 4(1): 1 11.

16. Beuckels, A., Depraetere, O., Vandamme, D., Foubert, I., Smolders, E. and Muylaert, K. (2013). Influence of organic matter on flocculation of Chlorella vulgaris by calcium phosphate precipitation. Biomass and Bioenergy, 54: 107 - 114.

17. Harith, Z. T., Yusoff, F. M., Mohamed, M. S., Shariff, M., Din, M. and Ariff, A. B. (2009). Effect of different flocculants on the flocculation performance of flocculation performance of microalgae, Chaetoceros calcitrans, cells. African Journal of Biotechnology, 8(21): 5971 - 5978.

18. Oh, H. M., Lee, S. J., Park, M. H., Kim, H. S., Kim, H. C., Yoon, J. H., Kwon, G. S and Yoon, B. D. (2001). Harvesting of Chlorella vulgaris using a bioflocculant from Paenibacillus sp. AM49. Biotechnology Letters, 23(15): $1229-1234$.

19. Vandamme, D., Foubert, I., Meesschaert, B. and Muylaert, K. (2010). Flocculation of microalgae using cationic starch. Journal of Applied Phycology, 22(4): 525 - 530. 